\title{
Tallow Leaf Roller (suggested common name) Caloptilia triadicae (Davis) (Insecta: Lepidoptera: Gracillariidae) ${ }^{1}$
}

\author{
Kristen Bowers and Andrea Lucky²
}

\section{Introduction}

The tallow leaf roller, Caloptilia triadicae Davis (Lepidoptera: Gracillariidae), is an inconspicuous brown moth approximately $5 \mathrm{~mm}$ (1/4 inch) long (Figures 1 and 2). This species was first described from the southern United States in 2013, where it is an accidentally introduced species, presumably originating from China. Its host tree, Chinese tallowtree, Triadica sebifera (L.) Small (family Euphorbiaceae), is a deciduous, non-native invasive species from southern China and a serious disruptor of wetland and riparian ecosystems. Assemblages of adult Caloptilia triadicae moths can be found resting on the underside of leaves of the tallow tree in the early morning on warm summer days. Like most moths, the adults are primarily active at night. The damage that the tallow leaf roller causes to its host tree is primarily cosmetic, and therefore it is not considered a viable biological control agent against Chinese tallowtree. Several other biological control agents have been tested for effectiveness against Chinese tallowtree (Wheeler and Ding 2014), including the leaf beetle Bikasha collaris Baly (Coleoptera: Chrysomelidae) and the moth Gadirtha fusca Pogue (Lepidoptera: Nolidae) (Wheeler et al. 2017a), and may prove more effective.

Although the adult moth is inconspicuous, the leaf damage produced by the caterpillars is quite noticeable. During their early larval stages, caterpillars feed between the upper and lower leaf surfaces, creating tunnel-like structures known as mines that are visible in young tallowtree leaves.
Once the larvae exit the mines, they create rolls using the tallow leaves. One leaf may contain multiple rolls (Figures 3 and 4). Damage to the tallowtree is distinctive and can be so extensive that stunted shoot growth can be seen at the tops of trees up to six meters (20 feet) tall (Fox et al. 2012).

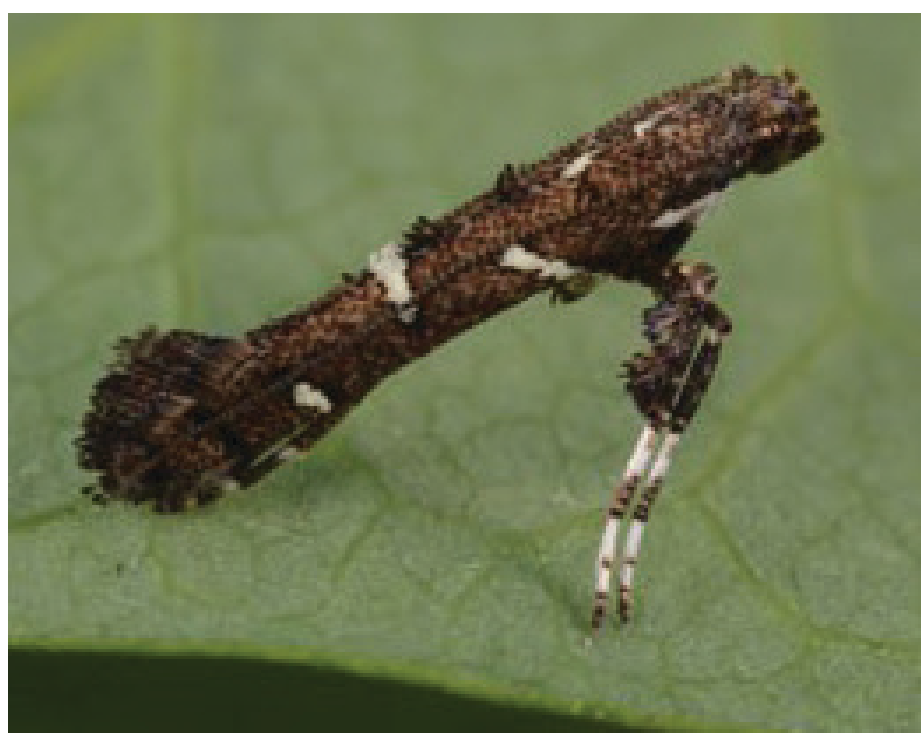

Figure 1. Adult tallow leaf roller moth, Caloptilia triadicae Davis. Credits: Lyle Buss, UF/IFAS

The moths were first described in 2013 (Davis et al. 2013), photographs and herbarium specimens indicate the tallow leaf roller has been in the southern United States since at least 2004 (Fox et al. 2012). The tallow leaf roller is presumed to have been introduced from China, because of its close association with the tallow tree, which has a native range restricted to southern China and northern Vietnam

1. This document is EENY-732, one of a series of the Entomology and Nematology Department, UF/IFAS Extension. Original publication date July 2019. Visit the EDIS website at https://edis.ifas.ufl.edu for the currently supported version of this publication.

2. Kristen Bowers; and Andrea Lucky; Entomology and Nematology Department, UF/IFAS Extension, Gainesville, FL 32611.

The Institute of Food and Agricultural Sciences (IFAS) is an Equal Opportunity Institution authorized to provide research, educational information and other services

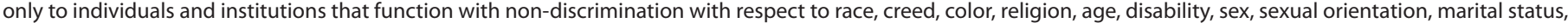

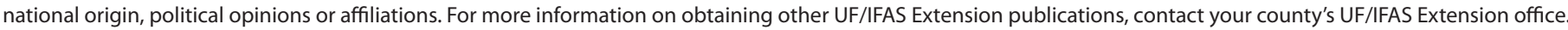
U.S. Department of Agriculture, UF/IFAS Extension Service, University of Florida, IFAS, Florida A \& M University Cooperative Extension Program, and Boards of County Commissioners Cooperating. Nick T. Place, dean for UF/IFAS Extension. 
(Esser 2002). Moreover, this species resembles three other species of Caloptilia from Asia that feed on trees in the genus Triadica (Davis et al. 2013). However, the tallow leaf roller has not been reported from its presumed native Chinese range (Davis et al. 2013). Fox et al. (2016) speculate that the moth is subject to a community of competitors in China, and thus has little impact on Chinese tallowtree in its native range.

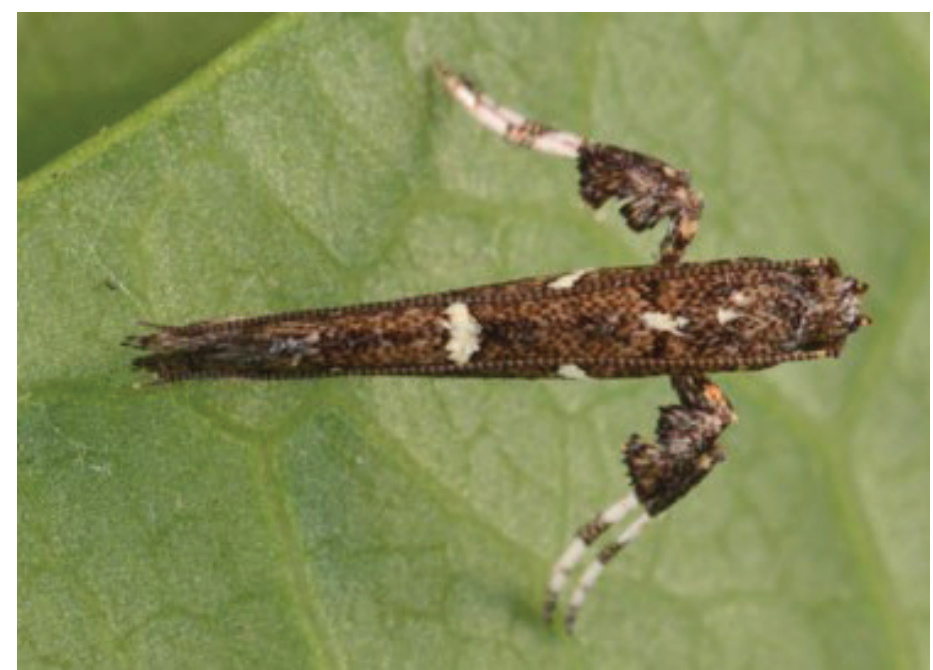

Figure 2. Adult tallow leaf roller moth, Caloptilia triadicae Davis. Credits: Lyle Buss, UF/IFAS

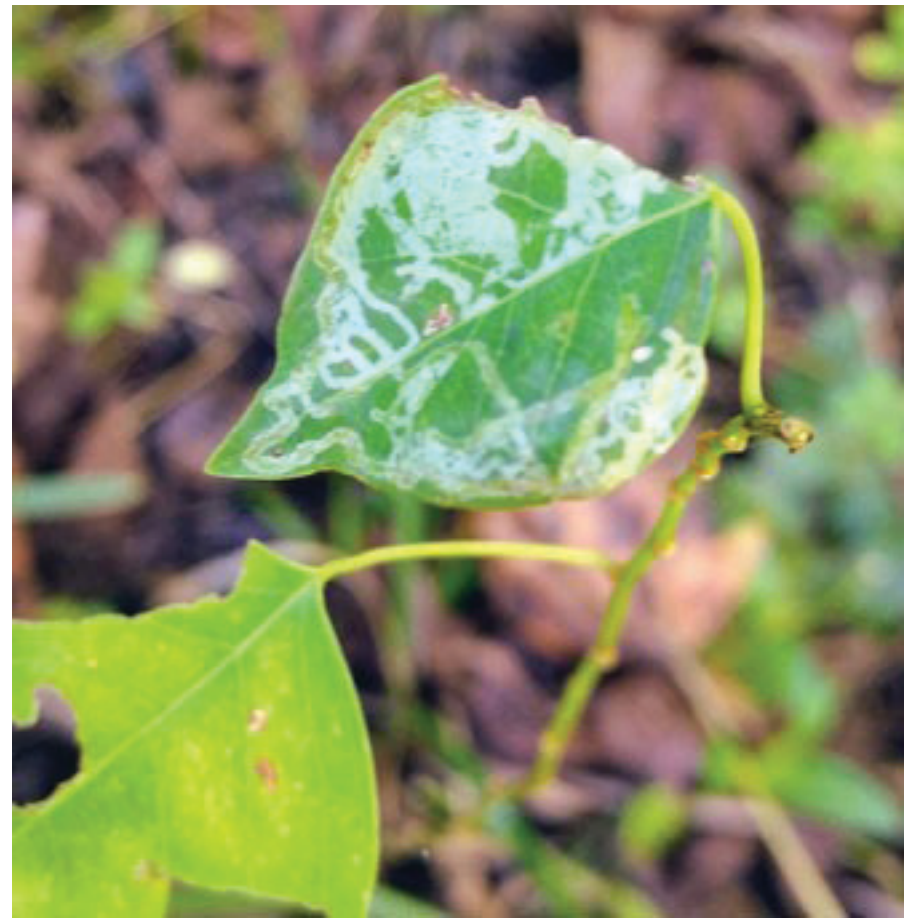

Figure 3. Mined leaf of Chinese tallowtree, Triadica sebifera, seedling. Credits: Kristen Bowers, UF/IFAS

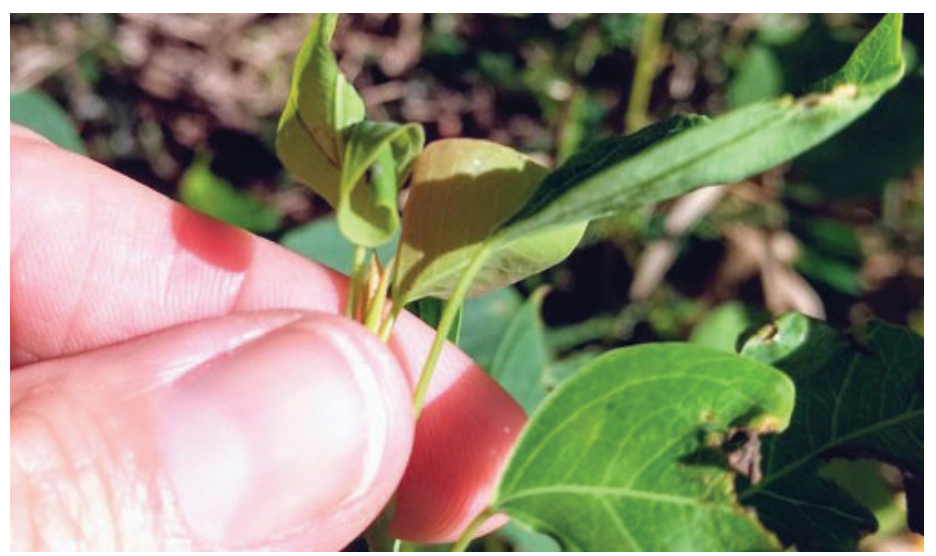

Figure 4. Rolled leaves of Chinese tallowtree, Triadica sebifera, seedling.

Credits: Kristen Bowers, UF/IFAS

\section{Distribution}

The first Florida collection of Caloptilia triadicae was in Gainesville in 2008 (Davis et al. 2013). Its host plant, the Chinese tallowtree, Triadica sebifera, was introduced to in 1905 by federal biologists, both for ornamental and oil production values (Pile et al. 2017).

The tallow leaf roller is found only in conjunction with tallow trees, and has been recorded in Florida, Alabama, Georgia, Louisiana, Mississippi, Texas, Oklahoma, South Carolina, and Tennessee (Davis et al. 2013). There are three other Caloptilia moth species known to feed on Triadica trees: Caloptilia octopunctata (from Australia and India), Caloptilia sapina (from South Africa), and Caloptilia sapiivora (from Japan). None of these species has been found in North America (Davis et al. 2013). The invasive potential of the other Caloptilia moths is unknown.

In Florida, there are dozens of other leaf mining moths in the family Gracillariidae. While most have no economic importance, this family also includes pest such as citrus peelminer, Marmara gulosa (Guillen and Davis), and the azalea leafminer Caloptilia azaleella (Brants) (Dekle 2010, Heppner 2016, Stelinkski 2016).

\section{Description}

\section{Eggs}

The eggs are flat, white, and attached to the Chinese tallow leaf surface. A single egg is approximately $0.3 \mathrm{~mm}(0.01$ inch) long (Davis et al. 2013).

\section{Larvae}

Early stages of the caterpillar are concealed under the leaf tissue. Close examination may reveal a pale larva in a mine. 


\section{Pupae}

Pupation occurs inside the leaf roll. Because the final stages of the caterpillars' development are concealed, it is difficult to determine when the larval stage ends and the pupal stage begins.

\section{Adults}

Adult moths are small, about $5 \mathrm{~mm}$ long, and brown with three white stripes on each wing and white marking on the legs (Davis et al. 2013). A discarded exuvia will be visible hanging out of the roll once the adult moth has emerged (Figure 5). A dichotomous key to the identification of the four species of Triadica feeding moths is found in Davis et al. (2013).

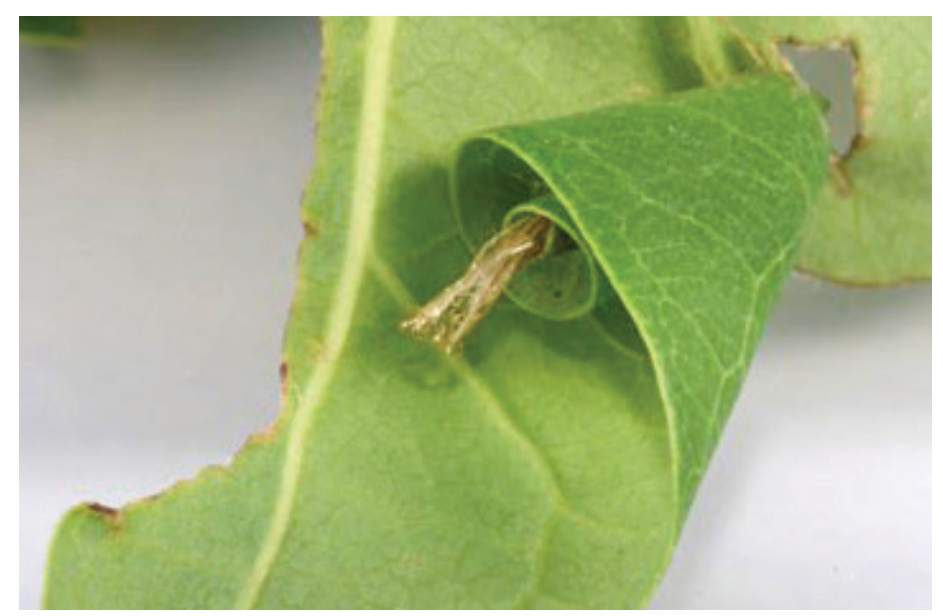

Figure 5. Pupal exuvia of a tallow leaf roller moth Caloptilia triadicae Davis, inside a leaf roll.

Credits: Lyle Buss, UF/IFAS

\section{Life Cycle and Biology}

The female moth deposits eggs one at a time on either the upper or lower surface of a new leaf. Larvae hatch and proceed to chew a tunnel between the upper and lower leaf surfaces, consuming sap as they create a mine which wanders through the leaf. A single leaf can support a number of larvae at a time, and mines in the upper and lower surface can be seen crossing over one another. After exiting a mine, a larva will chew across the leaf to form a flap of leaf tissue, which it will roll into a cone or rosette shape and secure with silk. Larvae pupate in the leaf roll. The adult moth emerges from the leaf roll, leaving behind a visible pupal case, known as an exuvia (Davis et al. 2013) (Figure 5).

Tallow moths can complete their lifecycle in less than a month, although the exact duration and number of larval instars has not been documented. Several generations of tallow moth are produced each year in Florida (Davis et al. 2013, Duncan et al. 2016). Mines and rolls can be observed as early as April or May in northern Florida, or about a month after new leaves appear on Chinese tallow trees in the spring. The overwintering habits of the tallow leaf roller are currently under investigation (Bowers, unpublished data). It has been suggested that pupae may overwinter in dried leaf rolls on the ground and emerge in the spring (Bowers, unpublished data).

\section{Hosts}

Chinese tallowtree, Triadica sebifera (L.), is the primary host of the tallow leaf roller. Tallow leaf rollers can proliferate in their invaded range to the extent that they cause stem dieback and even the death of Chinese tallowtree seedlings (Duncan et al. 2016).

Since its introduction, the Chinese tallowtree has been documented along the Gulf Coast from Florida to eastern Texas, and along the Atlantic Coast north to South Carolina, encompassing most of the southeastern states. Additionally, there are isolated populations of the tree in California (Figure 6) (EDDMapS 2017, Davis et al. 2013).

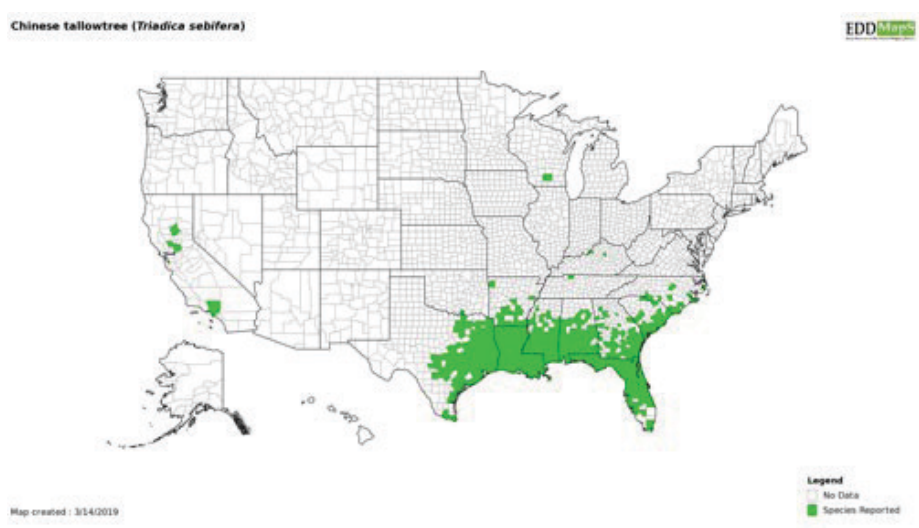

Figure 6. Map of Chinese tallowtree, Triadica sebifera (L.), distribution in the United States. http://www.eddmaps.org.

In Florida, invasive populations of Chinese tallowtree have been reported as far south as Lee County, around Fort Myers on the west coast of the state and to northern Palm Beach County, near Jupiter. More dense stands of the tree are found in Orange County and northward (EDDMapS 2017). Chinese tallow seeds germinate readily in the cooler conditions of Florida's panhandle (Bowers, unpublished data). Chinese tallowtree has a limited distribution in Florida's southern counties.

In outdoor choice tests including Chinese tallowtree and 41 other plant species in the families Euphorbiaceae, Phyllanthacaeae, and Putranjivaceae, the tallow leaf roller mined three native Florida tree species in addition to the Chinese tallowtree (Duncan et al. 2016). Tallow leaf roller mined both Sebastian bush, Ditrysinia fruticose (Bartram) 
Govaerts \& Frodin, and manchineel, Hippomane mancinella L. but no larvae completed development on either species (Duncan et al. 2016). The tallow leaf roller did complete its life cycle on oysterwood, Gymnathes lucida Sw., a native Florida plant, also in the family Euphorbiaceae (Wunderlin and Hansen 2008, Duncan et al. 2016). Oysterwood is native to the Bahamas, the Caribbean, Central America, and Florida. Whether the tallow leaf roller poses a future threat to oysterwood or other trees in the family Euphorbiaceae remains unknown.

\section{Economic Importance}

In larger Chinese tallow trees, the moths cause cosmetic damage to leaves but do not appear capable of controlling Chinese tallow in Florida (Wheeler et al. 2017b).

Although the current range of Chinese tallowtree and native oysterwood minimally overlap, the tallow leaf roller moth has been found causing cosmetic damage in ornamental plantings of oysterwood in Broward and Miami-Dade counties, which are well south of the range of Chinese tallowtree in Florida. The ability to utilize oysterwood appears to be an adaptation by the tallow leaf roller to its introduced range and is cause for concern. Oysterwood and Chinese tallowtree are closely related to trees in the genus Sapium; all three genera are members of the subtribe Hippomaninae. Sapium are native to the Caribbean and could be threatened if the tallow leaf roller finds its way south (Duncan et al. 2016).

\section{Management}

A variety of wasp and fly parasitoids are known to attack small shelter-building moths, including the tallow leaf roller. Tallow moths across Florida are attacked by a complex of native generalist hymenopteran parasitoids including Goniozus sp., Brasema sp., Sympiesis sp., and Zagrammosoma multilineatum. Tallow moth parasitoids are not considered a threat to the biological control agents currently under study.

In addition to parasitism, tallow leaf rollers are subject to predation by several arthropods, including polistine wasps, ants such as Pseudomyrmex gracilis (Fabricius), and various arachnids (Bowers, unpublished data). While it is unclear whether the spiders are using abandoned leaf rolls for shelter or consuming tallow leaf miner larvae, ants have been observed actively removing pupae from their rolls. (Davis et al. 2013).

\section{Selected References}

Davis DR, Fox MS, Hazen RF. 2013. Systematics and biology of Caloptilia triadicae (Lepidoptera: Gracillariidae), a new species of leaf-mining moth of the invasive Chinese tallow tree (Triadica sebifera (L.) Euphorbiaceae). Journal of the Lepidopterists' Society 67: 281-290. https://doi. org/10.18473/lepi.v67i4.a5

Dekle GW. 2010. Azalea Leafminer. Gainesville: University of Florida Institute of Food and Agricultural Sciences. EENY-379. http://entnemdept.ufl.edu/creatures/orn/ shrubs/azalea_leafminer.htm. (14 October 2017)

Duncan JG, Steininger MS, Wright SA, Wheeler GS. 2016. "Host range of Caloptilia triadicae (Lepidoptera: Gracillariidae): An adventive herbivore of Chinese tallowtree (Malpighailes: Euphoriaceae)." Florida Entomologist 99: 142-145. https://doi.org/10.1653/024.099.0132

EDDMapS. 2017. Early Detection and Distribution Mapping System. The University of Georgia - Center for Invasive Species and Ecosystem Health. Available online at http://www.eddmaps.org/. (14 October 2017).

Esser H-J. 2002. A revision of the Triadica Lour. (Euphorbiaceae). Harvard Papers in Botany 7: 17-21.

Fox M, Hazen R, Wheeler GS, Davis DR. 2012. "Using Internet images to gather distributional data for a newly discovered Caloptilia species (Lepidoptera: Gracillariidae) specializing on Chinese tallow in North America." American Entomologist 58: 32-35.

Heppner JB. 2016. Citrus leafminer. Gainesville: University of Florida Institute of Food and Agricultural Sciences. EENY-38. http://entnemdept.ufl.edu/creatures/citrus/ citrus_leafminer.htm. (14 October 2017).

Pile LS, Wang GG, Stovall JP, Evan S, Wheeler GS, Gabler CA. 2017. Mechanisms of Chinese tallow (Triadica sebifera) invasion and their management implications - A review. Forest Ecology and Management 404: 1-13. https://doi. org/10.1016/j.foreco.2017.08.023

Rogers WE, Siemann E. 2004. "Invasive ecotypes tolerate herbivory more effectively than native ecotypes of the Chinese tallow tree Sapium sebiferum." Journal of Applied Ecology 41: 561-570. https://doi. org/10.1111/j.0021-8901.2004.00914.x 
Rogers WE, Siemann E. 2005. "Herbivory tolerance and compensatory differences in native and invasive ecotypes of Chinese tallow tree (Sapium sebiferum)." Plant Ecology 181: 57-68. https://doi.org/10.1007/s11258-005-3029-6

Stelinkski LL. 2016. Citrus peelminer. Gainesville: University of Florida Institute of Food and Agricultural Sciences. EENY-415. http://entnemdept.ufl.edu/creatures/citrus/ citrus_peelminer.htm. (14 October 2017).

Wheeler GS, Ding J. 2014. "Is Chinese tallowtree, Triadica sebifera, an appropriate target for biological control in the United States?" Invasive Plant Science and Management 7: 345-359. https://doi.org/10.1614/IPSM-D-13-00061.1

heeler GS, Dyer K, Hight SD, Wright SA. 2017a. "Seasonal abundance of the adventive Chinese tallowtree herbivore Caloptilia triadicae (Lepidoptera: Gracillariidae) and its parasitoids." Florida Entomologist 100: 52-56. https://doi. org/10.1653/024.100.0109

Wheeler GS, Hight SD, Wright SA. 2017b. "Impact of field densities of the naturalized defoliator Caloptilia triadicae (Lepidoptera: Gracillariidae) on the invasive weed Chinese tallowtree." Environmental Entomology 46: 1305-1312.

https://doi.org/10.1093/ee/nvx148

Wunderlin RP, Hansen BF. 2011. Guide to the Vascular Plants of Florida. 3rd edition. 783 pp. 